\title{
Idiographic roles of cooperating teachers as mentors in pre-service distance teacher education
}

\author{
Ebru Melek Koç* \\ Izmir Institute of Technology, Academic Writing Center, 35430 Urla, Izmir, Turkey
}

\section{A R T I C L E I N F O}

\section{Article history:}

Received 6 May 2011

Received in revised form

2 March 2012

Accepted 8 March 2012

\section{Keywords}

Mentor roles

Cooperating teachers

Distance teacher education

Practicum

\begin{abstract}
A B S T R A C T
This study aims to define the roles of cooperating teachers as mentors in the context of distance-learning teacher education. The participants included 358 cooperating teachers who mentored 4 th-year student teachers in a Distance English Language Teacher Training Program in Turkey. To determine the roles that were perceived as mentoring roles by the cooperating teachers in the distance practicum, an inventory of 10 primary mentoring functions was constructed. These functions included five primary mentoring roles: 'self-trainer', 'networker, 'social supporter', 'academic supporter', and 'psychological supporter'. The results will contribute to an increased understanding of how cooperating teachers perceive their mentoring roles during distance practicums.
\end{abstract}

(C) 2012 Elsevier Ltd. All rights reserved.

\section{Introduction}

Different definitions of mentoring exist in the literature. Murphy, Mahoney, Chen, Mendoza-Diaz, and Yang (2005) present a broad definition of mentoring: 'Mentoring is a one-on-one relationship between an expert and a novice in which the expert guides the novice through behavioral and cognitive modeling, academic and career counseling, emotional and scholarly support, advice, professional networking and assessment' (p. 344). Crasbon, Hennisen, Brouwer, Korthagen, and Bergen's (2011) definition of mentoring is more specific to the teacher education context. These authors define mentoring as the one to one support of a student teacher by a more experienced teacher (2011, p. 321).

However, there is no agreed-upon definition of mentoring in teacher education (Lai, 2010, p. 444) because teacher education includes a variety of contexts, such as pre-service teacher education, in-service education, and distance teacher education. Thus, there is a lack of agreement on roles and expectations with the mentoring system (Duquette, 1994; Guyton \& McIntyre, 1990; Hall, Draper, Smith, \& Bullough, 2008). Ganser (2002) indicates that cooperating teachers (CTs) were confused about their roles as mentors. Along the same lines, Dunne and Dunne (1993) suggest that the quality of mentoring is affected by the mentors' lack of training, lack of a commonly identified mission and lack of clear

\footnotetext{
* Tel.: +90 2327506272.

E-mail address: ebrukoc@iyte.edu.tr.
}

perception. The literature also highlights the importance of identifying and clarifying the expectations of the roles of the triad to foster a better understanding of the student teacher experience (Duquette, 1997; Rikard \& Veal, 1996; Tsui, Lopez-Real, Law, Tang, \& Shum, 2001). Therefore, it is necessary to identify the mentor's roles during the teacher education practicum.

Furthermore, little research exists on the purpose of mentor roles (Jazwiak, 2010). Therefore, such a study will contribute to the research on mentor roles and, more specifically, provide valuable information on how cooperating teachers perceive their roles during the distance practicum; in addition, such a study will provide a definition of mentoring to fill the gap in the literature on 'mentoring roles'.

\subsection{Idiographic aspect of mentoring}

Finkelstein, Allen, and Rhoton (2003) indicate that the characteristics of mentorship are shaped by variables such as the duration of mentoring, the regularity of interaction and organizational level. Burg (2010) similarly explains how context shapes mentoring roles. The aim of mentoring changes with each mentoring context based on the needs of the mentor and the protégé. This malleability generates the 'idiographic' component of mentoring. In general, the idiographic component refers to how particular experimental phenomena (an event, process or relationship) have been understood from the perspective of particular people, in a particular context' (Smith, Flowers, \& Larkin, 2009, p. 29). Burg (2010; p. 311) defines the idiographic component as those aspects that are 
'specific to the needs of the protégé (and mentor)'. Burg (2010) also found that mentoring has a teleological component because the goals of the protégé or mentor may differ from one context to another, and the needs and goals of both the protégé and the mentor may change (Burg, 2010, p. 311).

\subsection{Mentoring in teacher education}

Teaching practice is an integral part of pre-service teacher education (Tanruther, 1994; p. 167), as it provides student teachers with the essential bridge between theory and practice and the opportunity to define and refine their teaching skills. Similarly, the current literature supports the importance of teacher practice, identifies student teaching as the most helpful part of professional education and comprises the first steps of a personal journey of becoming a teacher (Thibeault, 2004; Walkington, 2005; Williams, 2001). In a traditional student teaching experience model, student teachers are assigned to teachers (cooperating teachers) to be supervised throughout the practicum. Additionally, students are supervised by a university supervisor who occasionally visits the school (Zeichner, 2006). The university supervisor and the cooperating teacher in the classroom serve as mentors to the student teachers, as both of them interact with the protégé and help him or her gain the necessary professional knowledge and skills (Healy \& Welchert, 1990).

In school-based pre-service teacher education, mentoring refers to the supervision of a student teacher by an experienced teacher during the teaching practice period in a public school (Hamel \& Jaasko-Fisher, 2011; McIntyre, Hagger \& Wilkin, 1993). Similarly, Tomlinson (1995) defines mentoring in student teacher practice as 'assisting student teachers to learn how to teach in school-based settings and thus a mentor is anyone involved more or less directly with the student for that purpose' (p. 7).

\subsubsection{Theoretical framework}

There is no single, comprehensive theoretical framework that explains mentoring and the functions of mentoring (Jacobi, 1991; Mullen, 2005; Philip \& Hendry, 2000). Research on mentoring has used more than one theoretical concept to frame theory (Davidian, 2010; Hamilton, 2010; Menegat, 2010). Therefore, there is a tendency to apply theoretical frameworks from various disciplines when studying any particular mentoring context (Mullen, 2005). Kram's mentor role theory and Wang and Odell's (2007) mentoring approaches are considered to frame the present study. Kram (1985) identified two primary mentor functions: psychosocial functions and career functions. Psychosocial functions are interpersonal components of mentoring and include support through role modeling, acceptance, confirmation, counseling and friendship. On the other hand, 'Career functions' focus on the protégé's skill development and include forms of academic support, such as helping the protégé develop and learn how to teach.

Wang and Odell (2007) make note of approximately three approaches to mentoring. 'Humanistic mentoring' reflects the mentor's 'psychological/emotional support'. Mentors create a trustful atmosphere for protégées, help them to overcome problems that they encounter during their teaching practices and gain self-esteem so that they can be effective teachers. However, this approach does not explain how mentees learn teaching from their mentors. 'Situated-apprentice mentoring', which refers to the 'technical support' or 'contextualized guidance' that mentors provide (Wang \& Odell, 2007, p. 476), is the second approach. In this approach, mentors help protégées learn practical knowledge and bridge theory with practice and promote protégées' teaching skills and techniques. However, this conception of mentoring lacks the vital role of the deconstruction/reconstruction learning process.
Critical constructivist mentoring is the mentoring approach that focuses on the transformation of knowledge that guides learning. In this approach, the protégé criticizes/deconstructs existing knowledge and transforms/reconstructs it for teaching (Wang \& Odell, 2007).

\subsection{Background information}

\subsubsection{Traditional English Language Teacher Training Programs and} student teaching experience

In Turkey, undergraduate English Language Teacher Training Programs (ELTTPs) are implemented by education faculties. This program is a four-year undergraduate program. In traditional ELTTPs, student teachers take a school-based teacher practice course during their final year. The triad members of the practicum are the university supervisors, the cooperating teachers and the student teachers. The university supervisor is a faculty member from the university who oversees and supervises the student teachers during the student teaching experience. The university supervisor is responsible for organizing the practicum process and has the following duties: to select cooperating teachers and make a weekly schedule for each student teacher; to inform student teachers about the implementation of the course, the cooperating school, the guidelines to follow, the evaluation of the university supervisor's responsibilities and the student teachers' responsibilities during the teaching practice; and to introduce the student teachers to the headmaster, school coordinator and cooperating teacher. According to the handbook that was prepared by the Turkish Higher Education Council (HEC, 1998, p. 9), other responsibilities of a university supervisor include the following: to visit the cooperating school at scheduled dates to discuss the progress of the student teacher with the cooperating teacher; to guide the student teacher in lesson planning, observation and classroom management; to guide the student teacher in reaching the goal of self evaluation; to observe the student teacher for at least two full lessons during the semester; to assist the student teacher in preparing lesson plans for presentations; to provide written and oral feedback to the student teacher regarding his/her lesson plans; to serve as a source consultant for the student teachers and all of the teachers in the cooperating school; and to evaluate the activities and progress of the student teacher in collaboration with the cooperating teacher.

The second triad member of the practicum is the cooperating teacher. In the present study, the cooperating teacher is an inservice English language teacher to whose class the student teacher is assigned. The student teachers are assigned to a cooperating school and an experienced English language teacher who works in that school and acts as a cooperating teacher. The number of the students that a cooperating teacher supervises ranges from seven to eight. In the handbook that was prepared by HEC (1998, p. 10), the responsibilities of cooperating teachers include the following: to work with the university supervisor in planning the student teacher's schedule; to aid the student teacher's professional development; to introduce the cooperating school to the student teacher and supply the student teacher with necessary equipment and resources; to assist the student teacher with lesson planning and daily activities; observe the student teacher's work at the cooperating school and evaluate him/her; to keep, for each student teacher, a portfolio, which consists of observation and evaluation forms that assess the student teacher's activities and progress; to fill in an observation form for each of the student teacher's lesson presentations and make the completed observation forms and feedback available to the student teacher; to check the student teacher file periodically with the university supervisor; to aid the student teacher's professional development; to assist the 
student teacher with extra-curricular activities (e.g., meetings and seminars) in the cooperating school; and to evaluate the student teacher with the university supervisor at the end of the practicum.

The student teacher in the present study is a university student who participates in an ELTTP. Student teachers are required to make observations of the cooperating teacher, develop lesson plans and practice teaching in the cooperating school, and attend a seminar lesson in which they share their feelings and experiences with their university supervisor and peers.

One day prior to the beginning of their teaching practice, the groups meet their university supervisor and review the lesson plans together. The university supervisor observes each student twice each term. After each observation, he/she fills in an observation form for each lesson presentation of the student teacher and makes the completed observation forms and feedback available to the student teacher. Similarly, the cooperating teacher observes the student teachers, completes an observation form and provides feedback to the student teachers after the student teachers' performances. The student teachers' lesson plans, teaching performance and portfolio are periodically evaluated. Before deciding on final grades, the university supervisor contacts the cooperating teacher and requests the grades for each student teacher.

\subsubsection{Distance English Language Teacher Training Program}

Due to the increasing demand for English language teachers, an alternative ELTTP, named the 'Distance English Language Teacher Training Programme (DELTTP)', was begun with the co-operation of the Turkish Ministry of National Education and Anadolu University in 2000. The DELTTP is a four-year undergraduate program. During the first two years of the DELTTP, student teachers receive primarily face-to-face education. In the third and fourth years, the student teachers take part in distance learning. During this period, the instruction is print-based. For each course, student teachers have printed materials (course books). Student teachers do not take courses online. Nevertheless, 'online learning support' in the form of asynchronous instruction is provided for the student teachers to help them better comprehend the course books and prepare for the tests. For each course unit, a text-based document providing extra information on the subject, extra activities for supporting learning and a post test for evaluating learning is uploaded to the website. In addition, for specific courses, the course instructor has a virtual office hour during which online discussions are conducted.

During the final year of the program, Anadolu University Open Education Faculty (AUOEF) assigns each student teacher to a public school that is located in the student teacher's city. Each student teacher is assigned to an English language teacher for mentoring throughout the practicum year. The mentor teachers do not receive special training prior to the practicum, but they are provided with a practicum handbook that is prepared for the student teachers and the cooperating teachers by the university. Additionally, the student teachers are responsible for observing the cooperating teacher, creating lesson plans and writing reflection reports. The cooperating teachers are required to check the student teachers' lesson plans prior to their teaching practice, observe the student teachers, provide feedback, maintain a portfolio of the lesson observation assessment forms for each student teacher, grade each portfolio and deliver student teachers' portfolios to the school administrator so that they can be sent to the evaluation committee at the university. At the end of the year, each student teacher's portfolio, which includes graded lesson plans, observation forms, student teachers' reflection reports, and evaluation forms, is sent to the Course Evaluation Committee at the university. The course evaluation committee evaluates the students' portfolios in pairs. The student teachers' final grades are based on the assessments of the cooperating teacher ( $50 \%$ of the final grade) and the evaluation committee ( $50 \%$ of the final grade).

There are differences between the traditional pre-service ELTTP and the distance ELTTP. The most significant difference lies in the mentoring process. Whereas the student teachers in the traditional ELTTP are supervised by both a university supervisor and a cooperating schoolteacher during their teaching practice, the student teachers in the distance ELTTP are mentored only by the cooperating teacher who is assigned by the university. The university supervisors visit the schools once or twice a year to provide on-site support to the practicum process. In addition, the students have the opportunity to contact the university supervisor by e-mail or by telephone.

\section{Methodology}

\subsection{Participants}

In 2007, 432 cooperating teachers supervised 2463 student teachers who were enrolled in their final year of the DELTTP throughout the year. Of these 432 cooperating teachers, 358 participated in the study. In total, 293 of the cooperating teachers work at a high school, whereas the remainder work at an elementary school. In total, 235 of the cooperating teachers are female, whereas 123 are male. In total, 248 of the CTs comprise graduates of an ELT program. Of the 358 cooperating teachers, 235 supervise six student teachers. In total, 23 of the cooperating teachers had $0-5$ years of teaching experience, whereas the other cooperating teachers had teaching experience that ranges from 6 to 20 or more years. With regard to the number of students who were mentored, most (65.6\%) of the CTs stated that they supervised 6 student teachers. CTs who indicated that they supervised to 1, 2, 3 or 4 student teachers constitute only $5.1 \%(N=19)$ of the total.

\subsection{Data collection tool}

To determine which roles the cooperating teachers perceived as their mentoring roles, the teachers' perceptions were investigated through interviews. To generalize the study findings, an inventory was constructed to include as many mentors as possible in the study. Many measurements have been used to study mentoring functions. For example, Noe (1988) assessed the career-related and psychosocial functions of mentoring. Ragins and McFarlin's (1990) 'Mentor Role Instrument' measured the career dimension and the psychosocial dimension of mentoring. Scandura and Katerberg's (1988) 18-item 'Mentor Functions Questionnaire' assessed three types of mentor support: career support, psychosocial support and role modeling support. Cohen's (1993) 'Principles of Adult Mentoring Scale' focused on mentoring in adult education and counseling. Rose's (2003) 'Ideal Mentor Scale' investigated the qualities of mentors that are preferred by graduate students in higher education. The literature provides a variety of tools that are related to mentoring, but none of these tools has addressed the context of distance pre-service teacher education. Therefore, to investigate the mentors' self- perceived roles during the distance practicum, it was necessary to construct a new, valid and reliable mentor role instrument.

In the next section, information will be provided on the construction of the inventory and the testing of its reliability and validity.

\subsubsection{Construction of Cooperating Teacher Role Inventory (CTRI)}

To construct the items of the questionnaire, the researcher first conducted a deep literature review and created a list of cooperating teacher functions. Additionally, data collected by means of 
interviews and free writing were used to construct the pool items. Ten weeks after the beginning of the practicum, 10 cooperating teachers and 10 student teachers were asked to write their ideas on the topic, "What should be the roles of cooperating teachers who supervise student teachers at the distance ELTT programme during the teaching practicum?' Ten more cooperating teachers and 10 student teachers were interviewed about their views on the roles of cooperating teachers. All interviews were conducted individually and tape recorded after obtaining the participants' permission. The interview data were transcribed, and the transcribed data from the interviews and the written data from the free-writing exercises were analyzed to construct the items of the instrument. To analyse the qualitative data, all meaningful information from the student teachers' interviews and free writing was highlighted and added to the pool as separate items. Then, all items in the pool were analyzed, and items with similar meanings were clustered. Each cluster was re-analyzed to construct a representative item. At the end of the analysis, a 61-item inventory of the functions of a mentor was constructed.

2.2.1.1. Validity of the CTRI. Content and face validity were achieved through the use of a panel of experts and a pilot study. To achieve content validity, the questionnaire was analyzed by five experts in the field. After the questionnaire items were edited according to the expert educators' comments, the number of the items decreased to 54. The final judgment of the instrument was made by three experts from the Educational Sciences Department who were specialists in constructing questionnaires. After their feedback,the final version of the questionnaire consisted of 58 items (Koç, 2011).

For face validity, the final version of the 'Cooperating Teacher Role Inventory' was administered to nine cooperating teachers to identify any unclear items. Modifications for improvement of the instrument were made according to the recommendations of the cooperating teachers.

The final version of the CTRI consisted of two parts. The first part gathered demographic information, such as the teachers' age, gender, educational background, teaching experience, and types of schools at which they worked. The second part consisted of 58 items related to their perceived mentoring functions. Next to the items was a grid that consisted of five columns that were designed according to a five-point Likert scale with values 1 (never), 2 (rarely), 3 (sometimes), 4 (often), and 5 (always).

\subsection{Data collection procedures}

The CTRIs were posted to 432 cooperating teachers who were assigned as mentors to student teachers during their school-based teaching practice. By the time of the data collection, the cooperating teachers had been participating in the practicum process for ten weeks. Of the 432 cooperating teachers, 358 (82.87\%) completed and returned the CTRI to the researcher. The construction of the CTRI and the data collection lasted six months.

\subsection{Data analysis procedure}

The raw data from the questionnaires were coded and loaded into the Statistical Program for Social Sciences (SPSS) version 15.0. To determine the reliability of the questionnaire, a factor analysis was conducted to summarize the questions within valid and plausible components, and Cronbach's alpha $(\alpha)$ values were calculated to check the internal reliability of the scale, in addition to individual factors. Factor analysis was used as a data reduction technique that takes a large set of variables and looks for a way to reduce or summarize the data through the use of a smaller set of components (Pallant, 2001). Principal component analysis was applied as the extraction method because it is popular in the research field and easy to interpret (Pallant, 2001).

\subsubsection{Factorisation of the CTRI}

Before the factor analysis, Bartlett's test of sphericity and the Kaiser-Meyer-Olkin Measure of Sampling (KMO) values were calculated to measure the suitability of the data. The initial solution of the factor analysis revealed a KMO value of 0.911 , which is regarded as superb (Hutcheson \& Sofroniou, 1999). Bartlett's test of sphericity $\left(\chi^{2}=7710.422\right.$ ) with a $\mathrm{p}$-value of 0.005 revealed an ideal Approx, meaning that the correlation matrix was proper at a statistically significant level to perform factor analysis (Pallant, 2001).

Factorial validity was tested using a principal component analysis. Items with loadings less than 0.4 were removed from the scale, and items with very close loadings under different components were deleted from the analysis to prevent multicollinearity (Coombs \& Schroeder, 1988; Dunteman, 1989; Field, 2000; Pallant, 2001). The analysis of the CTRI indicated that the Cronbach's alpha value was 0.928 . The principle component analysis identified ten factors and 43 indicators accounting for $60.196 \%$ of the total variance. This value is better than the value considered acceptable in the social sciences (Dunteman, 1989). This indicates that the Cooperating Teacher Role Inventory is a valid and reliable instrument that could be used in the present study. The variance explained by each component is illustrated in Table 1 . The factors were rotated through Varimax Rotation for interpretation. The items included in each factor, the reliability coefficients of factors and the Varimax rotation loadings are provided in Table 2.

\section{Results and discussion}

The findings of the study revealed that the cooperating teachers identified the following tasks as their mentoring responsibilities: 'Providing facilitative information to enhance classroom performance', 'Giving constructive feedback on teaching performance', 'Helping student teachers form a professional identity and become aware of their professional development', 'Providing moral support', 'Facilitating socialization of the student teacher', 'Scaffolding lesson planning', 'Willingly offering facilitative information', 'Helping students to use and understand observation forms', 'Preparing for the mentor role' and 'Interacting with other cooperating teachers'. The cooperating teachers perceived these 10 mentor functions to be their responsibilities during the distance practicum.

The findings align with Wang and Odell's (2007) conceptions of mentoring. For example, 'providing moral support' is the primary focus of humanistic conceptions of mentoring. Alternatively, the mentor functions of 'Providing facilitative information to enhance classroom performance', Facilitating socialization of the student teacher', and 'Willingly offering facilitative information' seem to be more related to practical knowledge and are aimed at helping the protégés to become a part of the existing teaching culture. That is, these functions align with the situated-apprentice mentoring approach.

The most common mentor approach perceived by the cooperating teachers seems to be 'critical constructive mentoring'. Dialogs between a mentor and a protégé mostly occur during feedback sessions. During feedback sessions, the mentor provides feedback on the protégé's lesson plan and on his/her teaching style in the classroom. The protégé asks questions to clarify misunderstood points. During this negotiation, the protégé learns to reflect critically, transform the new knowledge and deconstruct/reconstruct the knowledge to learn about how to teach. Therefore, the functions of 'Giving constructive feedback on teaching performance', 'Helping 
Table 1

Results of the FactorA analysis: total variance explained.

\begin{tabular}{|c|c|c|c|c|c|c|c|c|c|}
\hline \multirow[t]{2}{*}{ Factor } & \multicolumn{3}{|c|}{ Initial Eigenvalues } & \multicolumn{3}{|c|}{ Extraction sums of squared loadings } & \multicolumn{3}{|c|}{ Rotation sums of squared loadings } \\
\hline & Total & $\%$ of variance & Cumulative \% & Total & $\%$ of variance & Cumulative \% & Total & $\%$ of variance & Cumulative \% \\
\hline 1 & 13.030 & 29.613 & 29.613 & 13.030 & 29.613 & 29.613 & 5.540 & 12.591 & 12.591 \\
\hline 2 & 2.264 & 5.145 & 34.759 & 2.264 & 5.145 & 34.759 & 3.761 & 8.547 & 21.138 \\
\hline 3 & 1.927 & 4.380 & 39.139 & 1.927 & 4.380 & 39.139 & 2.953 & 6.712 & 27.850 \\
\hline 4 & 1.636 & 3.718 & 42.857 & 1.636 & 3.718 & 42.857 & 2.581 & 5.867 & 33.717 \\
\hline 5 & 1.606 & 3.650 & 46.507 & 1.606 & 3.650 & 46.507 & 2.256 & 5.127 & 38.843 \\
\hline 6 & 1.435 & 3.262 & 49.769 & 1.435 & 3.262 & 49.769 & 2.080 & 4.727 & 43.570 \\
\hline 7 & 1.254 & 2.851 & 52.620 & 1.254 & 2.851 & 52.620 & 2.012 & 4.572 & 48.142 \\
\hline 8 & 1.192 & 2.709 & 55.329 & 1.192 & 2.709 & 55.329 & 1.969 & 4.475 & 52.617 \\
\hline 9 & 1.092 & 2.483 & 57.812 & 1.092 & 2.483 & 57.812 & 1.740 & 3.954 & 56.571 \\
\hline 10 & 1.049 & 2.384 & 60.196 & 1.049 & 2.384 & 60.196 & 1.595 & 3.625 & 60.196 \\
\hline 11 & 0.987 & 2.243 & 62.439 & & & & & & \\
\hline 12 & 0.956 & 2.172 & 64.611 & & & & & & \\
\hline 13 & 0.914 & 2.078 & 66.689 & & & & & & \\
\hline 14 & 0.860 & 1.954 & 68.643 & & & & & & \\
\hline 15 & 0.830 & 1.887 & 70.531 & & & & & & \\
\hline
\end{tabular}

Extraction Method: Principal Component.

to use and understand observation forms', 'Scaffolding lesson planning', and 'Helping to use and understand observation forms' seem to refer to the critical constructivist mentoring approach.

These mentoring functions are interrelated, and when they cluster, a multidimensional role phenomenon for the mentors is constructed that includes academic supporter, psychological supporter, social supporter, self-trainer and networker.

\subsection{Academic supporter}

Factor analysis revealed ten subscales that are related to mentor functions during the distance practicum. Of these subscales, seven of them ('Providing facilitative information to enhance classroom performance', 'Giving constructive feedback on teaching performance', 'Helping student teachers to form a professional identity and be aware of their professional development', 'Scaffolding lesson planning', 'Willingly offering facilitative information', and 'Helping to use and understand observation forms') are related to the provision of support for student teachers' development of teaching skills and professional knowledge. All of these factors refer to the teaching process during which one significant role of the cooperating teacher is to assist student teachers in making educational theory meaningful for its successful application to the real teaching experience. Such a sucessfuul assistance requires the cooperating teacher to serve as a role model for the students teachers, demonstrate a range of teaching techniques, help them develop their classroom management, lesson planning, assessment and evaluation skills. These mentoring functions are associated with academic work, therefore, are clustered and referred to as 'academic support'. In mentoring literature, some have named this function 'career support' (Dilmore, Rubio, Cohen, Seltzer, Switzer, Bryce et al., 2010; Kram, 1985). Others referred to it as 'vocational or instrumental support' (Ensher \& Grant-Vallone, 2002), and 'instrumental support' (Duquette, 1998).

A significant finding is that out of ten mentor functions, seven are related to academic support. This relationship indicated that cooperating teachers perceived the mentor role of academic supporter' to be a dominant responsibility when compared with other roles. The literature also supports this finding (Abell, Dillon, Hopkins, McInerny, \& O'Brien, 1995; Cisneros, 2011; Lowenstein, 2006). This finding is not surprising. Cooperating teachers receive a handbook from the university to use as a resource. The handbook contains information that guides the mentoring relationship and information on the roles of the practicum members. In this document, most of the listed cooperating teachers' responsibilities relate to instructional support. Therefore, it is likely that the cooperating teachers feel that they are obliged to fulfill these responsibilities.

\subsection{Psychological supporter}

On the CTRI, the subscale 'Providing moral support' (Table 2) clusters items that are related to nurturing the student teacher's self-esteem, motivation, confidence and trust. Because all of the items refer to the emotional aspect of mentoring, this subscale corresponds with the 'psychological supporter' role of a mentor. This correspondence aligns with Kram's mentor role theory, in which a mentor's psychosocial support is regarded as one of the two main roles of a mentor. This subscale was found to have the fourth highest Cronbach's alpha value, 0.74 (Table 2), which seems to indicate that cooperating teachers do not regard acting as a provider of psychological support as their major mentor role. This finding is consistent with the literature. Lowenstein (2006) also found that career functions featured more significantly than psychosocial functions.

\subsection{Social supporter}

The results of the present study indicated that another mentoring responsibility that is perceived by the cooperating teachers was facilitating student teachers' socialization by introducing them to administrators, staff and co-teachers and inviting them to school activities (Table 2). This mentoring function was found to have a Cronbach's alpha value of 0.634 (Table 2 ).

One aspect of socialization is becoming a member of a social community. Socialization is the mutual interaction of the teacher and the school setting that involves the administrator, colleagues and personnel. In the literature, socialization is referred to as 'organizational socialization' (Kelchtermans \& Ballet, 2002, p. 106) and 'occupational socialization' (Woodford, 2002). Socialization begins with the student teacher's entrance into the undergraduate program, where he/she begins to acquire the specialized knowledge and skills that are associated with his/her career, and it continues throughout teacher education (Kelchtermans \& Ballet, 2002; Woodford, 2002).

Wasburn-Moses (2009) found that both student teachers and new teachers may not have accurate expectations of their positions and may lack sufficient information to fulfill their roles because of a gap between the expectations and roles of current teachers. In this sense, field experience has a positive effect on teachers' role 
Table 2

Means, standard deviations, alpha coefficients, and Varimax rotation loadings.

\begin{tabular}{|c|c|c|c|c|}
\hline \multicolumn{2}{|c|}{ Items and factors } & \multirow[t]{2}{*}{ Mean } & \multirow[t]{2}{*}{ SD } & \multirow{2}{*}{$\begin{array}{l}\text { Varimax } \\
\text { factor load }\end{array}$} \\
\hline Fact & 1: Providing facilitative information to enhance classroom performance $(\alpha=0.897)$ & & & \\
\hline 23 & I share with the student teachers information about the effective methods to use in establishing classroom discipline & 4.399 & 0.785 & 0.768 \\
\hline 43 & I give feedback to the students teachers about how to establish classroom discipline & 4.397 & 0.735 & 0.732 \\
\hline 27 & I advice the student teachers on how to establish close relationship with the pupils & 4.426 & 0.694 & 0.692 \\
\hline 44 & I give feedback to the student teachers about how to participate the learners to the lesson by taking their attention & 4.554 & 0.642 & 0.668 \\
\hline 26 & I provide with suggestions about effective classroom management techniques to the student teachers & 4.403 & 0.670 & 0.626 \\
\hline 14 & I give information to the student teachers about the rules and policies they are to obey at the cooperating school & 4.461 & 0.708 & 0.586 \\
\hline 24 & I assist the student teachers to compare the theory taught at the university with their observations at the cooperating school & 4.303 & 0.770 & 0.561 \\
\hline 45 & $\begin{array}{l}\text { I give feedback to the student teachers about how to organize classroom activities such as pair work } \\
\text { and group work activities effectively }\end{array}$ & 4.374 & 0.699 & 0.505 \\
\hline 25 & I explain the principles underlying certain teaching techniques to the student teachers whenever s/he needs & 4.157 & 0.809 & 0.493 \\
\hline 15 & $\begin{array}{l}\text { I share with the student teachers information about how to operate and use the technical equipments } \\
\text { such as video, OHO, type-recorder, etc }\end{array}$ & 4.371 & 0.810 & 0.492 \\
\hline 12 & I share with the student teachers information about the interests, skills, and level of success of the pupils in the class & 4.370 & 0.715 & 0.470 \\
\hline \multicolumn{5}{|c|}{ Factor II: Giving feedback on teaching performance $(\alpha=0.823)$} \\
\hline 39 & I give feedback not only about the weaknesses of the student teachers, but also about their strong sides & 4.629 & 0.621 & 0.680 \\
\hline 38 & I give detailed feedback to the student teachers about their teaching performance & 4.482 & 0.686 & 0.661 \\
\hline 40 & I let the student teachers ask me questions about the feedback I have provided them about their teaching performance & 4.651 & 0.593 & 0.643 \\
\hline 42 & I give feedback to the student teachers about their language skills & 4.208 & 0.833 & 0.571 \\
\hline 31 & I observe the student teachers' lessons carefully when they are teaching in the classroom & 4.793 & 0.439 & 0.563 \\
\hline 37 & $\begin{array}{l}\text { Before giving feedback to the student teachers about their teaching performance, I let them } \\
\text { reflect about their own teaching performance }\end{array}$ & 4.447 & 0.742 & 0.502 \\
\hline \multicolumn{5}{|c|}{ Factor III: Helping student teachers' form a professional identity and be aware of their professional development $(\alpha=0.818)$} \\
\hline 52 & I guide the student teachers in solving their own problems in the most proper way whenever they encounter a problem & 4.559 & 0.581 & 0.716 \\
\hline 51 & $\begin{array}{l}\text { I encourage the students in sharing their problems they encounter during their teaching practice and } \\
\text { suggest solutions to each other on how to deal with these }\end{array}$ & 4.485 & 0.664 & 0.662 \\
\hline 48 & While evaluating the student teachers, I take into consideration their progress throughout the practicum & 4.647 & 0.556 & 0.564 \\
\hline 50 & $\begin{array}{l}\text { I encourage the student teachers in making their own decisions in the classroom so that they can gain experience } \\
\text { on deciding which of them are effective and which ones are not }\end{array}$ & 4.360 & 0.737 & 0.562 \\
\hline 54 & I assist the student teachers in constructing their own teacher identities & 4.565 & 0.618 & 0.519 \\
\hline 53 & I help the student teachers to be aware of the factors which affect the decisions they make during their teaching practice & 4.287 & 0.725 & 0.514 \\
\hline \multicolumn{5}{|c|}{ Factor IV: Providing moral support $(\alpha=0.749)$} \\
\hline 6 & I encourage the students so that they believe in themselves & 4.810 & 0.407 & 0.808 \\
\hline 5 & I create a trustful atmosphere in which the student teachers can share their thoughts with relief & 4.731 & 0.498 & 0.718 \\
\hline 8 & I encourage the student teachers when they are discouraged about lesson planning or teaching a lesson in the class & 4.777 & 0.456 & 0.605 \\
\hline 7 & I make the student teachers feel that they are a part of the teaching staff at the cooperating school & 4.584 & 0.597 & 0.460 \\
\hline \multicolumn{5}{|c|}{ Factor V: Facilitating socialization of the student teacher $(\alpha=0.634)$} \\
\hline 19 & I arrange opportunities for the student teachers to observe other teachers' classrooms & 3.073 & 1.179 & 0.704 \\
\hline 10 & I introduce the student teachers to the administrators, staff, co-teachers and other school employees & 3.910 & 0.961 & 0.643 \\
\hline 18 & I invite the student teachers to the school activities and staff meetings & 3.564 & 1.138 & 0.575 \\
\hline \multicolumn{5}{|c|}{ Factor VI: Scaffolding lesson planning ( $\alpha=0.721$ ) } \\
\hline 29 & I check the lesson plans of the student teachers and give feedback before they teach at the class & 4.510 & 0.679 & 0.709 \\
\hline 30 & $\begin{array}{l}\text { I check the lesson plans of the student teachers again in order to see whether they have edited } \\
\text { their lesson plans according to my previous feedback }\end{array}$ & 4.342 & 0.733 & 0.610 \\
\hline 28 & I assist the student teachers to reach necessary sources during their lesson preparations & 4.378 & 0.733 & 0.595 \\
\hline \multicolumn{5}{|c|}{ Factor VII: Willingly offering facilitative information $(\alpha=0.500)$} \\
\hline 55 & $\begin{array}{l}\text { I check the student teachers' all lesson plans and give feedback to the student teachers about } \\
\text { them at the end of the teaching practice period }\end{array}$ & 4.243 & 1.202 & 0.702 \\
\hline 58 & When the student teachers encounter a problem, I tell them how it could be solved & 4.587 & 0.689 & 0.635 \\
\hline 41 & $\begin{array}{l}\text { After I teach a lesson, I do reflection on my teaching performance so that the student teachers can take me as a } \\
\text { model when they are reflecting their own teaching performance }\end{array}$ & 4.237 & 0.786 & 0.447 \\
\hline \multicolumn{5}{|c|}{ Factor VIII: Preparation for the mentor role $(\alpha=0.566)$} \\
\hline 1 & I read the guide book about the teaching practicum which AÖF prepared for the student teachers and cooperating teachers & 4.232 & 0.796 & 0.685 \\
\hline 2 & I interact with the cooperating school coordinator during the practicum & 4.043 & 1.110 & 0.659 \\
\hline 4 & I investigate other sources to gain information about the responsibilities of a cooperating teacher during the practicum & 3.598 & 1.080 & 0.495 \\
\hline \multicolumn{5}{|c|}{ Factor IX: Helping to use and understand observation forms $(\alpha=0.582)$} \\
\hline & I give the completed observation/evaluation forms to the student teachers after filling them & 4.048 & 1.161 & 0.690 \\
\hline & $\begin{array}{l}\text { I explain to the student teachers how to make use of the completed observation and evaluation } \\
\text { forms at the beginning of the school practice }\end{array}$ & 4.394 & 0.797 & 0.575 \\
\hline \multicolumn{5}{|c|}{ Factor $\mathrm{X}$ : Interacting with other cooperating teachers $(\alpha=0.505)$} \\
\hline & I compare the performance/marks of my student teachers with the other cooperating teachers' students' & 3.309 & 1.319 & 0.744 \\
\hline 3 & I interact with other cooperating teachers who mentor other AÖF/IÖLP student teachers & 4.449 & 0.859 & 0.724 \\
\hline
\end{tabular}

(Extraction: Principal Component; Rotation: Varimax with Kaiser Normalization.). 
identity (Fant, 1996). The cooperating teacher's continuous attention to roles helps the student teacher to construct a 'teacher identity' and to become a member of the 'teachers' society'.

Mentoring is a significant part of the socialization process (Colwell, 1998; Lanier \& Little, 1986). Colwell (1998) claims that a 'mentor should help the protégé develop the necessary skills for teaching, and become aware of the values and roles of the profession, and any associated institutions, thus providing a framework for them to hang their professional expertise on'. Thus, mentoring is a radical form of socialization (p. 320). Hobson, Ashby, Malderez, and Tomlinson (2009) mention that by helping protégés to adapt to the norms of teaching, mentors 'socialize' the protégés, and protégés become aware of the standards to be maintained within the profession. As a 'social supporter', a mentor prepares the student teacher to be a member of the 'teachers' society'. In other words, the mentor helps the protégé to adapt to norms that are associated with teaching (Hobson et al., 2009). Before facing the school environment, teachers should have some basic knowledge of the organizational life of schools. If student teachers are not equipped with information about school politics, they may fail to overcome problems that arise from schools' institutional characteristics (Kuzmic, 1994, p.24; Rust, 1994).

\subsection{Networker}

The component 'Interacting with other cooperating teachers', which has a Cronbach's alpha value of 0.505 and $2.3 \%$ total variance, seems to be perceived by the cooperating teachers as the least important mentoring function (Table 2). This mentoring function suggests that the cooperating teachers who are assigned as mentors to the student teachers in the distance ELT program are in need of 'interaction' with other cooperating teachers. This mentoring function can refer to the mentor role of 'networker'. A similar 'networking' role was suggested by Tenenbaum, Crosby, and Gliner (2001) to refer to the facilitation of connections with other people in the discipline. 'Networking' is identified as characterizing one of the three main roles of a mentor (Koeppen \& Mckay, 2000; Murphy et al., 2005).

\subsection{Self-trainer}

The subcategory 'Self-preparation for the mentor role' is among the mentor functions that are considered the least important and has a Cronbach's alpha value of 0.56 (Table 2). This mentoring function refers to the efforts of the cooperating teachers to gain information about mentoring and the mentoring process during the practicum through sources such as the practicum handbook and other people who are involved in the process. This subcategory of mentoring seems to differ from the other mentoring functions in that it refers to actions that allow for the development of the mentoring skills of the cooperating teacher rather than developing the professional skills of the student teachers. In this sense, this mentor function is equivalent to the mentor role of 'self-trainer'. It is striking that in the past, the literature has not defined such a role for mentors. It seems that this role is unique to mentors in the distance education setting, which supports the view that a mentor's roles are unique for each context because the needs of the protégé and the mentor shape these roles (Burg, 2010).

The results of the findings indicate that mentors need to prepare themselves for a better understanding of mentoring roles, which suggests that the concept of mentoring and mentor roles has not been clearly conceptualized by the mentors who supervise student teachers in the DELTTP. This lack of a clear conceptualization could exist because the DELTTP organizers do not give cooperating teachers support in developing their mentoring skills prior to or during the practicum process. The cooperating teachers who mentor student teachers in distance education do not have the opportunity to work regularly and cooperatively with a university mentor. Therefore, the mentors do not receive regular face-to-face feedback or solutions for the problems that they encounter during the supervisory process. The university mentor of the distance ELT program makes a formal visit to the cooperating schools only once or twice a year, and these visits offer the cooperating teachers their only opportunity to share their problems and receive guidance from the university supervisor in person. Although the mentors can interact with the university mentors via mail, e-mail or phone, they may not feel comfortable with the solitude of distance learning and may prefer face-to-face interactions with other cooperating teachers who are in charge of distance-learning student teachers. This isolation may explain why a mentor in a distance-learning teacher education setting adopts the roles of 'networker' and 'self-trainer'.

In the literature, one of the mentor roles is the 'evaluator' (Brooks \& Sikes, 1997; Feiman-Nemser \& Parker, 1993; Hopper, 2001). According to the distance program's evaluation procedure, the cooperating teachers are required to evaluate the work of student teachers through formal evaluations that are periodically recorded in each student's portfolio and are sent to the course evaluator committee at the Open Faculty at the end of each term. The cooperating teachers are expected to share equal responsibility in the evaluation process with the course evaluator committee. Studies that are conducted in traditional pre-service teacher education settings revealed the 'evaluator' as a distinct mentoring role of the cooperating teachers (Demirkol, 2004; Shippy, 1989). Therefore, it was notable that the mentors in this study did not perceive 'evaluation' or 'assessing student teachers' performance' as part of their responsibilities. This result could be interpreted as 'role conflict' that exists among the cooperating teachers. The mentors believe that their major role is that of the 'supporter'. However, the 'evaluator/assessor' role seems to conflict with the 'supporter' role (Hudson, Usak, \& Savran-Gencer, 2009; Kwan \& Lopez-Real, 2005). Similarly, Benton (1990) noted that if assessment is not managed successfully, mentors are likely to have a negative experience. Therefore, although the cooperating teachers are required to share the responsibility of evaluation with the course evaluator committee at the Open Faculty, to prevent negative outcomes, they may prefer to act as passive mentors in an 'unsubstantial position' (Ramanthan \& WilkinsCanter, 2000).

\section{Conclusions}

The present study was aimed at the investigation of the idiographic roles of mentors who supervise student teachers in distance-learning pre-service teacher education programs during practicum. The findings indicated that the mentors take on five main roles: 'self-trainer', 'networker', 'social supporter', 'academic supporter', and 'psychological supporter'. It is striking that the mentor role of 'self-trainer' has not been identified as a specific mentor role in the literature. This lack of identification could be due to contextual factors. This finding is valuable in that it confirms the idiographic nature of mentoring of which Burg (2010) has previously noted. That is, the specific needs of mentors and protégés determine the mentor's role. The mentors in the present study are not trained in their mentoring roles and the mentoring process. In addition, in opposition to the cooperating teachers who mentor student teachers in traditional teacher education programs, the mentors in the distance teacher education program do not have the opportunity to receive face-to-face guidance from university-based mentors. The mentors can only phone or e-mail the university- 
based mentors in the programs, which does not appear to be practical. Therefore, to provide themselves with the required information and mentoring skills, the mentors train themselves by reading the handbook that is provided by the faculty, asking help from other mentors, and so on.

The results of this study have provided a better understanding of how cooperating teachers perceive their roles during practicum. Clarity of role definition is the basis for a productive mentoring (supervisory) partnership (Bradley, 2011; Zachary, 2000). Taking this fact and the findings of the present study into consideration, organizers of teacher education programs with contextual factors that are similar to those of the present study could use this information to shape or reshape the definition of a 'mentor' in their programs. Such a redefinition is likely to increase the mentor and the protégé's awareness of their reciprocal roles and minimize potential problems, such as 'role conflict' and 'role strain'. By identifying mentor roles, this study may partly fill the gap in the body of literature on mentor roles in terms of a definition of mentoring.

The study is also significant in that it provided a better understanding of which mentoring approaches mentors use. Although there is evidence that most mentors are flexible in their mentoring approaches (Williams, Butt, Gray, Leach, Marr \& Soares, 1998), the present study appears to show that mentors use three mentoring approaches that are cited by Wang and Odell (2007). Most of the mentoring approaches used by the cooperating teachers appear to relate to Wand and Odell's (2007) 'critical constructivist approach'. Critical and reflective thinking are the key issues in this approach. However, the present study does not examine whether student teachers pose questions about new knowledge, critique existing knowledge and transform it for their teaching. Similarly, the study does not indicate whether mentors encourage critical thinking in protégés. Therefore, a further qualitative study in which data that is collected through observations and interviews that focus on these issues may provide a deeper understanding of how mentors learn teaching or whether mentors use the critical constructivist approach properly.

Another outcome of this study is the construction of a data collection tool (the Cooperating Teacher Role Inventory, CTRI), which is aimed at the investigation of the perceptions of cooperating teachers regarding their mentor roles. This tool could be a major contribution to the mentoring literature through the development of a valid and reliable instrument for identifying mentors' role perceptions. Although the present study is limited to the context of the distance education English language teacher training, further investigation may adopt the tool in other teacher education contexts.

\subsection{Suggestions for improving mentorship}

Student teachers who are provided with effective mentorship are likely to experience professional growth (Moehle, 2011). Therefore, steps should be taken to improve the mentor-protégé relationship. The findings of this study indicated that cooperating teachers are 'self-trainers' due to the inadequate educational opportunities that are provided by the faculty. However, the quality of such 'self-training' is questionable. The quality of student teaching experience is extremely important, and the quality of this experience depends on the flourishing collaboration of triad/dyad members (Darden, Darden, Scott \& Westfall, 2001; Metcalf-Turner \& Fischetti, 1996). Therefore, a closer link between teacher educators and cooperating schools should be established. University supervisors have a vital role in strengthening this link. Because they serve as the liaison between the university and the cooperating school (Swisher, 2011), they have a vital role in strengthening school-faculty communication. Making frequent visits to cooperating schools, which are scattered across a sizable geographic area, may be costly and time-consuming for university-based mentors. Using computer-mediated communication could be a solution to this problem. Through web-support, including synchronized question-answer sessions, cooperating teachers acquire the information that is necessary for mentoring and develop a better understanding of their mentoring.

Another suggestion for increasing mentorship quality is to provide specific mentoring training. Such mentoring preparation is one of the conditions for effective mentoring (Hobson et al., 2009). Such training can help cooperating teachers develop their mentoring skills, which include coaching, advising, reflection, providing critical feedback and assessment (Rodgers \& Keil, 2007). During this training, the cooperating teachers should be informed of mentoring approaches because for effective mentoring, mentors should know which mentoring approaches to use and when to use them. Training can also help cooperating teachers to develop a better understanding of their mentor roles.

\section{Acknowledgements}

This study was partly supported by a grant of the Anadolu University Scientific Research Project Commision. I would like to thank the anonymous reviewers, the editors for their constructive feedback, and Prof. Dr. Zülal Balpınar for her academic support.

\section{References}

Abell, S. K., Dillon, D. R., Hopkins, C. J., McInerny, W. D., \& O’Brien, D. G. (1995). Somebody to count on: mentor/intern relationships in a beginning teacher internship program. Teacher and Teacher Education, 11(2), 173-188.

Benton, P. (1990). The Oxford internship scheme: Integration and participation in initial teacher education. London: Calouste Gulbenkian Foundation.

Bradley, K. (2011). The influence of mentoring relationships on Novice K-12 teachers' experiences. Unpublished doc. of Ed dissertation. Walden University.

Brooks, V., \& Sikes, P. (1997). The good mentor guide: Initial teacher education in secondary schools. Buckingham: Open University Press.

Burg, C. A. (2010). Faculty perspectives on doctoral student mentoring: The mentor's Odyssey. Unpublished doctorate dissertation. University of South Florida, USA.

Cisneros, A.L. (2011). The impact of training mentor and student teachers' self efficacy in physical education. Unpublished master of science dissertation. The University of Texas at El Paso.

Cohen, N. H. (1993). Development and validation of the principles of adult mentoring scale for faculty mentors in higher education. Unpublished doctoral dissertation. Temple University. Dissertation Abstracts International, 54, 02A-0400. (UMI No. 9316468).

Colwell, S. (1998). Mentoring, socialisation and the mentor/protégé relationship. Teaching in Higher Education, 3(3), 313-324.

Coombs, W., \& Schroeder, H. (1988). An analysis of factor analytic data. Personality and Individual Differences, 9, 79-85.

Crasborn, F., Hennisen, P., Brouwer, N., Korthagen, F., \& Bergen, T. (2011). Exploring a two-dimensional model of mentor teacher roles in mentoring dialogues. Teaching and Teacher Education, 27, 320-331.

Darden, G., Darden, A., Scott, K., \& Westfall, S. (2001). The student-teaching experience. Journal of Physical Education, Recreation \& Dance, 72(4), 50-53.

Davidian, M. R. (2010). Health information management education: A comparison of faculty mentoring in traditional vs. distance education programs. Unpublished $\mathrm{PhD}$ dissertation. Claremont Graduate University, California.

Demirkol, I. (2004). Expectations for the roles of cooperating teachers and university supervisors during the practice teaching period as perceived by university supervisors, cooperating teachers and student teachers. Unpublished master's thesis. Boğaziçi University, Istanbul.

Dilmore, T. C., Rubio, D. M., Cohen, E., Seltzer, D., Switzer, G. E., Bryce, C., et al. (2010). Psychometric properties of the mentor role instrument when used in an academic medicine setting. Communications, 3(3), 104-108.

Dunne, E., \& Dunne, R. (1993). The purpose and impact of school-based work: the class teacher's role. In N. Bennet, \& C. Carre (Eds.), Learning to teach. London: Routledge.

Dunteman, G. H. (1989). Principal component analysis: Quantitative applications in the social sciences series, Vol. 69. Thousand Oaks, CA: Sage Publications.

Duquette, C. (1994). The role of the cooperating teacher in a school based teacher education programme: benefits and concerns. Teaching and Teacher Education, $10,345-354$.

Duquette, C. (1997). Conflicting perceptions of participants in field-based teacher education programs. Journal of Education, 32(3), 263-272. 
Duquette, C. (1998). Perceptions of mentor teachers in school-based teacher education programs. Journal of Education for Teaching, 24(2), 177-179.

Ensher, E. A., Grant-Vallone, E. J., \& Marelich, W. D. (2002). Effects of perceived attitudinal and demographic similarity on protégés support and satisfaction gained from their mentoring relationships. Journal of Applied Social Psychology, 32(7), 1407-1430.

Fant, G. R. (1996). An investigation of the relationships between undergraduate music education students' early field experience and student teaching performance (Unpublished doctoral dissertation). University of Arizona, Tucson.

Feiman-Nemser, S., \& Parker, M. (1993). Mentoring in context: a comparison of two U.S. programs for beginning teachers. International Journal of Educational Research, 19, 699-718.

Field, A. (2000). Discovering statistics using SPSS for windows. London: Sage Publications.

Finkelstein, L. M., Allen, T. D., \& Rhoton, L. A. (2003). An examination of the role of age in mentoring relationships. Group and Organization Management, 28(2), 249-281.

Ganser, T. (2002). How teachers compare the roles of cooperating teacher and mentor. The Educational Forum, 66(4), 380-385.

Guyton, E., \& McIntyre, D. J. (1990). Student teaching and school experience. In W. R. Houston (Ed.), Handbook of research on teacher education (pp. 514-534). New York: Macmillan.

Hall, K. M., Draper, R. J., Smith, L. K., \& Bullough, R. V., Jr. (2008). More than a place to teach: exploring the perceptions of the roles and responsibilities of mentor teachers. Mentoring $\mathcal{E}$ Tutoring: Partnership in Learning, 16(3), 328-345.

Hamilton, J. (2010). Cooperating teachers: An investigation into their needs and training as mentors and supervisors of student teachers. Unpublished doctoral dissertation. The University of San Francisco.

Hamel, F. L., \& Jaasko-Fisher. (2011). Hidden labor in the mentoring of pre-service teachers: Notes on a mentor teacher advisory council, Teacher and Teacher Education, 27(2), 434-442.

Healy, C. C., \& Welchert, A. J. (1990). Mentoring relations: A definition to advance research and practice. Educational Researcher, 19(19), 17-21.

HEC (Turkish Higher Education Council). (1998). Fakülte-Okul İșbirliği. [FacultySchool Cooperation]. Ankara.

Hobson, A. J., Ashby, P., Malderez, A., \& Tomlinson, P. D. (2009). Mentoring beginning teachers: what we know and we don't. Teaching and Teacher Education, 25 207-216.

Hopper, B. (2001). The role of the HEI tutor in initial teacher education school-based placement. Mentoring $\mathcal{E}$ Tutoring, 9(3), 211-222.

Hudson, P., Usak, M., \& Savran-Gencer, A. (2009). Employing the five-factor mentoring instrument: analysing mentoring practices for teaching primary science. European Journal of Teacher Education, 32(1), 63-74.

Hutcheson, G., \& Sofroniou, N. (1999). The multivariate social scientist. London: Sage.

Jacobi, M. (1991). Mentoring and undergraduate academic success: a literature review. Review of Educational Research, 61(4), 505-532.

Jazwiak, M. M. (2010). In-service teachers' beliefs and perceptions regarding mentoring preservice teachers: A critical look at the transformative possibilities within professionally development school partnerships. Unpublished doctoral dissertation. New Mexico: New Mexico State University.

Kelchtermans, G., \& Ballet, K. (2002). The micropolitics of teacher induction. A narrative-biographical study on teacher socialization. Teaching and Teacher Education, 18, 105-120.

Koç, E. M. (2011). Development of mentor teacher role inventory. European Journal of Teacher Education, 34(2), 193-208.

Koeppen, K. E., \& Mckay, J. W. (2000). Who is telemachus? Long-term mentoring in education. Teacher Development, 4(3), 425-436.

Kram, K. E. (1985). Mentoring at work: Developmental relationships in organizational life. Glenview, IL: Scott, Foresman and Company.

Kuzmic, J. (1994). A beginning teacher's search for meaning: teacher socialisation, organisational literacy, and empowerment. Teaching and Teacher Education, 10(1), 15-27.

Kwan, T., \& Lopez-Real, F. (2005). Mentors' perceptions of their roles in mentoring student teachers. Asia-Pacific Journal of Teacher Education, 33(3), 275-287.

Lai, E. (2010). Getting in step to improve the quality of in-service teacher learning through mentoring. Professional Development in Education, 36(3), 443-469.

Lanier, J. E., \& Little, J. W. (1986). Research on teacher education. In M. C. Wittrock (Ed.), Handbook of research on teaching (3rd ed.). New York: Macmillan.

Lowenstein, S. R. (2006). Behind every great star: A mentoring guide for school of medicine faculty and administrators. Retrieved April 25, 2012 from. http:// www.uchsc.edu/som/faculty/MentoringWebPDF.pdf.

McIntyre, D., Hagger, H., \& Wilkin, M. (Eds.). (1993). Mentoring: Perspectives on school-based teacher education. London: Kogan Page.

Menegat, G. M. (2010). Mentor/Protégé interactions and the role of mentor training within a novice teacher mentoring program. Unpublished doctoral dissertation. Lewis \& Clark College.
Metcalf-Turner, P., \& Fischetti, J. (1996). Professional development schools" Persisting questions and lessons learned, Journal of Teacher Education, 47, 292-299.

Moehle, M. R. (2011). A mixed methods study exploring strengths-based mentoring in clinical practice and student teacher development. Unpublished doctoral dissertation. University of Nebraska.

Mullen, C. A. (2005). Mentorship primer. New York, NY: Peter Lang.

Murphy, K. L., Mahoney, S. E., Chen, C.-Y., Mendoza-Diaz, N. V., \& Yang, X. (2005) A constructivist model of mentoring, coaching, and facilitating online discussions. Distance Education, 26(3), 341-366.

Noe, R. A. (1988). An investigation of the determinants of successful assigned mentoring relationships. Personnel Psychology, 41(3), 457-479.

Pallant, J. (2001). SPSS survival manual. Maidenhead, PA: Open University Press.

Philip, K., \& Hendry, L. B. (2000). Making sense of mentoring or mentoring making sense? Reflections on the mentoring process by adult mentors with young people. Journal of Community and Applied Social Psychology, 10(3), $211-223$.

Ragins, B. R., \& McFarlin, D. B. (1990). Perceptions of mentor roles in cross-gender mentoring relationships. Journal of Vocational Behavior, 37, 321-339.

Ramanthan, H., \& Wilkins-Canter, E. (2000). Preparation of cooperating teachers as evaluators in early field experiences. Action in Teacher Education, 22(1), 101-111.

Rikard, G. L., \& Veal, M. L. (1996). Cooperating teachers: insights into their preparation, beliefs, and practices. Journal of Teaching in Physical Education, 15(3), 279-296.

Rodgers, A., \& Keil, V. L. (2007). Restructuring a traditional student teacher supervision model: fostering enhanced professional development and mentoring within a professional development school context. Teaching and Teacher Education, 23, 63-80.

Rose, G. L. (2003). Enhancement of mentor selection using the ideal mentor scale. Research in Higher Education, 44, 473-494.

Rust, F. (1994). The first year of teaching: it's not what they expected. Teaching and Teacher Education, 10(2), 205-217.

Scandura, T. A., \& Katerberg, R. J. (1988). Much about mentors and little about measurement: Development of an instrument. Paper presented at the annua meeting of the Academy of Management, Anaheim, CA

Shippy, V. S. (1989). An investigation of role expectations in the student teaching triad as viewed by student teachers, cooperating teachers and college supervisors. Unpublished dissertation. State University of New York, Albany.

Smith, J. A., Flowers, P., \& Larkin, M. (2009). Interpretive phenomenological analysis: Theory, method, and research. London: Sage.

Swisher, L. N. (2011). Examiming practicing teachers' understandings of mentoring and the student teaching field experience. Unpublished doctoral dissertation. University of Pennsylvania.

Tanruther, E. M. (1994). What does it mean to be a supervisory teacher? College Journal, (March), 167-171.

Tenenbaum, H. R., Crosby, F. J., \& Gliner, M. D. (2001). Mentoring relationships in graduate school. Journal of Vocational Behavior, 59(3), 326-341.

Thibeault, J. (2004). The relationship between student teachers and cooperating teachers as a foundation for the development of reflective thinking: An exploratory study based on student teachers' perceptions. Unpublished doctoral dissertation. McGill University, Montreal, Canada.

Tomlinson, P. (1995). Understanding mentoring. Buckingham: Open University Press.

Tsui, A. B. M., Lopez-Real, F., Law, Y. K., Tang, R., \& Shum, M. S. K. (2001). Roles and relationships in tripartite supervisory conferencing processes. Journal of Curriculum and Supervision, 16(4), 322-344.

Walkington, J. (2005). Becoming a teacher: encouraging development of teacher identity through reflective practice. Asia-Pacific Journal of Teacher Education, 33(1), 53-64

Wang, J., \& Odell, S. J. (2007). An alternative conception of mentor-novice relationships: learning to teach in reform-minded ways as a context. Teacher and Teaching Education, 23, 473-489.

Wasburn-Moses, L. (2009). An exploration of pre-service teachers' expectations for their future roles. Teacher Education and Special Education, 32(1), 5-16.

Williams, C. C. (2001). Student teacher perceptions of University supervisor performance. Unpublished doctoral dissertation. Tennessee State University, 2001.

Williams, E. A., Butt, G. W., Gray, C., Leach, S., Marr, A., \& Soares, A. (1998). Mentors' use of dialogue within a secondary initial teacher education partnership. Educational Review, 3(50), 225-239.

Woodford, P. (2002). The social construction of music teacher identity in undergraduate music education majors. In R.Colwell., \& C. Richardson (Eds.), The new handbook of research on music teaching and learning (pp. 675-694). New York: Oxford University Press.

Zachary, L. J. (2000). The mentor's guide: Facilitating effective learning relationships. San Francisco: Jossey-Bass.

Zeichner, K. (2006). Professional development school partnerships: a place for teacher learning. New Horizons for Learning, 12(2), April (Spring). 